\title{
PRO KONTRA PROSES PENGESAHAN UU NO. 16 TAHUN 2017, SERTA IMPLEMENTASI DAN IMPLIKASINYA TERHADAP ORGANISASI MASYARAKAT
}

\author{
Fadli Afriandi ${ }^{1}$, Fachriza Ariyadi ${ }^{2}$ \\ ${ }^{1}$ Departemen Politik dan Pemerintahan-UGM, ${ }^{2}$ IAIN Palu \\ e-mail: fadliafriandii@gmail.com,fachriza_ariyadi@iainpalu.ac.id
}

\begin{abstract}
This paper looks at how a public policy process is issued, implemented, and its implications. The policy issued was the stipulation of Law no. 16 of 2017 (Law on community organizations) in lieu of Perppu No. 2 of 2017 (Perppu for community organizations). The main thesis proposed in this paper is that the policy of passing the law on community organizations is an attempt by the state to protect the Pancasila ideology, which is the sole ideology in Indonesia. This paper is prepared using qualitative methods by collecting data through Library Research. The findings of this study are that the issuance of the first law on community organizations cannot be separated from debates in parliament. The parties in parliament are inconsistent with their party ideology. Supporting or rejecting the law on community organizations is based on the pragmatic interests of the party. Secondly, the existence of the Community Organization Law makes it difficult for community organizations to stand and makes it easier for the government to dissolve community organizations that are not under Indonesian ideology. Third, the first community organization that was dissolved after the law on community organizations took effect was the Islamic Defenders Front (FPI).
\end{abstract}

Keywords: ideology, public policy, community organization, implementation, Islamic Defenders Front

\section{PENDAHULUAN}

Tulisan ini berfokus kepada dinamika proses lahirnya Undang-Undang Nomor 16 Tahun 2017 (berikutnya UU ormas) sebagai Penetapan Peraturan Pemerintah Pengganti Undang-Undang Nomor 2 Tahun 2017 (berikutnya Perppu Ormas) Tentang Perubahan atas Undang-Undang Nomor 17 Tahun 2013 di lembaga legislatif, implementasi, dan implikasi dari pelaksanaan UU ormas tersebut terhadap organisasi masyarakat (ormas) keagamaan. Pentingnya tulisan ini dikaji berkaitan dengan pertama ormas di negara demokrasi sangat dibutuhkan dan diperbolehkan, meskipun legalnya ormas di sistem demokrasi tidak sejalan dengan usaha negara dalam pembatasan eksistensi ormas, kedua melihat penerapan dan dampak diterapkannya UU ormas terhadap ormas keagamaan. Tulisan ini beranjak dari pendekatan institusionalisme yang melihat perlunya negara mengontrol segala kegiatan yang nantinya akan berakibat buruk bagi keutuhan negara. Tulisan ini memberikan pembaharuan mengenai proses politik di parlemen sehingga lahirnya UU No. 16 Tahun 2017 dan Front Pembela Islam (FPI) sebagai korban UU ormas yang memiliki basis massa yang besar yang berdampak kepada derasnya arus pro dan kontra baik di level pemerintah maupun di tengah masyarakat Indonesia.

Dalam kehidupan berdemokrasi, dukungan masyarakat sipil sangat dibutuhkan. Masyarakat sipil sangat dibutuhkan dalam demokrasi dimana masyarakat sipil seperti agensi utama dalam demokrasi. Dalam pendekatan politik liberal yang dipaparkan oleh Robert Putnam "Making Democracy Work: Civic Traditions in Modern Italy" mengatakan bahwa masyarakat sipil dipentingkan dalam modal sosial baik dalam ruang publik maupun tata kelola pemerintah. Hal tercerimin dari trust dan kooperasi dipandang sebagai kualitas budaya yang dapat mendorong kemajuan proses demokrasi (Putnam dkk, 1993). Pendekatan Tocqueville mengatakan bahwa masyarakat sipil penting bagi negara karena dapat menghubungkan negara dengan masyarakat untuk menunjang proses demokrasi (Tocqueville, 2005). Pendekatan Neo-Tocquevillean menurut John Keane mengatakan bahwa masyarakat sipil dilihat sebagai sebuah golongan yang sempurna dalam mengungkap hubungan yang kompleks dan antusias dari sebuah lembaga legal non-pemerintah bersifat anti dengan kekerasan, mandiri, swakelola 
dan bergerak dalam bingkai aturan yang ada di dalam negara (Keane, 1998).

Salah satu bentuk dari gerakan masyarakat sipil adalah pembentukan organisasi kemasyarakatan (ormas). Ormas sebagai tempat dan arena untuk mewujudkan hak asasi manusia seperti mengeluarkan gagasan, berserikat, dan berkumpul. Tujuan dengan dibentuknya ormas adalah untuk dapat berkontribusi dalam pembangunan agar terwujudnya tujuan Indonesia yang berlandaskan Pancasila (Hairi, 2017).

Ormas mempunyai peran yang cukup krusial dalam sistem demokrasi. Hal ini dikarenakan bahwa ormas menjadi pilar demokrasi khususnya menciptakan sebuah masyarakat sipil yang tangguh dalam mengupayakan hak rakyat dapat diperoleh di sebuah negara. Didirikan ormas ini bertujuan dalam memikul, membantu, dan menunjang kegiatan atau kepentingan publik tanpa alih-alih memperoleh keuntungan secara materi (Herdiansah \& Randi, 2016: 50). Dalam UU ormas mengatakan bahwa ormas didirikan oleh masyarakat yang mempunyai kesamaan aspirasi yang bertujuan untuk berkontribusi dalam pembangunan negara.

Pasca reformasi di Indonesia, kehadiran ormas mempunyai fungsi dalam pembangunan. Diantara fungsi pembangunan ormas adalah ormas mampu mengelola cita-cita dan kehendak rakyat. Ormas juga mampu dalam mendukung pengembangan kesejahteraan rakyat (aspek ekonomi). Ormas hadir dalam mendukung dan juga ikut melakukan kegiatan pembangunan. Selain ikut dalam kegiatan pembangunan, ormas juga mendorong masyarakat untuk juga aktif dalam pembangunan dan mendorong mengembangkan keterampilan mereka. Tidak hanya ikut dalam pembangunan, ormas juga sebagai organisasi yang melakukan pengawasan terhadap pembangunan, dan menjaga keamanan dan ketertiban. Maka dari itu semuanya kehadiran ormas dapat sebagai intermediary actor yang menghubungkan antara masyarakat sipil dengan negara dan sekaligus kolega negara dalam pembangunan dan meningkatkan kesejahteraan (Herdianyah \& Rudi, 2016).

Ormas merupakan aktor reformist dalam sistem demokrasi. Hal ini dikarenakan besarnya peran ormas tersebut dalam kegiatan transformasi di negara-negara berkembang (Latifah \& Larasati, 2018:171). Di negara berkembang seperti Pakistan, ormas menjadi kolega negara khususnya dengan lembaga militer dalam program anti terorisme dan pengukuhan ketahanan msayarakat di sana (Mirahmadi dkk, 2016).

Ormas ini terbagi ke beberapa jenis. Setidaknya ada lima jenis ormas jika didasarkan pada tujuannya. Pertama, ormas berbasis masyarakat yang berorientasi kepada pemanfaatan sumber daya yang ada dan membangun kelompok masyarakat. Kedua, ormas filantrophi yang memberikan pelayanan berorientasi kemanusiaan. Ketiga, ormas serikat pekerja yang berbasis kepentingan pekerja tersebut. Keempat, ormas ahli yang bermaksud bergerak di ranah ilmu pengetahuan dan teknologi. Kelima adalah ormas keagamaan (Probosiwi, 2018)

Tulisan ini lebih berfokus kepada ormas keagamaan. Ormas keagamaan menurut Efzioni (1982) mempunyai kedudukan yang unik dibandingkan dengan ormas umum lainnya. Keunikan tersebut dilihat dari tiga hal yaitu pembentukan ormas tersebut bukan untuk mencari keuntungan finansial, berada di luar organisasi pemerintah, berorientasi kepada masyarakat, dan keanggotaanya yang masif (Hidayat, 2008: 9). Di Indonesia ormas keagamaan ini cukup menjadi perhatian. Selain kehadirannya yang cukup masif di level grass root, juga berkontribusi besar dalam kelompok elit. Ormas agama di Indonesia terdapat di seluruh agama yang diakui negara. Namun ormas Islam merupakan ormas keagamaan yang cukup besar di Indonesia.

Di Indonesia kehadiran ormas agama didukung oleh konstitusi. UUD 1945 Pasal 28E secara jelas mengatakan bahwa warganya berhak untuk berserikat, berkumpul, dan mengeluarkan pendapat. Selanjutnya UU No. 17 Tahun 2013 menjadi landasan hukum dalam pembentukkan ormas di Indonesia. Munculnya UU ini menjadikan menjamurnya kemunculan ormas-ormas. Dari kemunculannya terdapat ormas yang sejalan dengan empat pilar kehidupan berbangsa dan bernegara yaitu pancasila, UUD 1945, NKRI dan Kebhinekaan Tunggal Ika. Namun sebaliknya terdapat pula ormas yang tidak sejalan dengan empat pilar kehidupan berbangsa dan bernegara tersebut.

Pasca menilai belum efektifnya UU No. 17 Tahun 2013, maka kemudian ditetapkan UU No. 16 Tahun 2017. Sebelum UU No. 16 Tahun 2017 ini disahkan terdapat Perppu No. 2 Tahun 2017. Dari latar belakang inilah, tulisan ini melihat bagaimana dinamika pengesahan UU No. 16 Tahun 2017 di lembaga legislatif, implementasi, 
dan implikasinya terhadap ormas keagamaan (ormas Islam) di Indonesia.

\section{TINJAUAN PUSTAKA}

Kehadiran sebuah UU didasarkan kepada munculnya masalah di tengah masyarakat. Peran pemerintah di sini adalah bagaimana masalahmasalah yang ada di masyarakat diatasi dengan membentuk sebuah kebijakan publik. Kebijakan secara teoritis bertujuan untuk menyelesaikan masalah masyarakat (publik) tersebut (Kusumanegara, 2010: 65).

Studi mengenai kebijakan publik dikembangkan oleh Laswell yang secara sederhana mendefinisikan kebijakan publik sebagai hal-hal yang akan atau tidak dilakukan oleh pemerintah. Terdapat dua hal yang ditekankan di sini, yakni aktornya hanya pemerintah, dan sebagai pertimbangan melakukan sesuatu atau tidak oleh sang aktor (Laswell, 1956). Sementara menurut Anderson melihat bahwa pengambilan sebuah kebijakan adalah kolaborasi antara pemerintah dan aktor di luar pemerintah. Namun pemerintah tetap menjadi aktor utamanya (Anderson, 2003: 1-34). Berbeda dengan Laswell dan Anderson, Easton melihat kebijakan publik sebagai otoritas untuk mengalokasikan nilai kepada masyarakat secara luas. Maksudnya adalah terciptanya kebijakan sejalan dengan pendistribusian nilai kepada publik (Dye, 1972).

Pada dasarnya dalam kehidupan negara modern, politik berperan sebagai intrumennya. Sehingga sistem yang mengatur kehidupan bersama dikenal dengan sebutan sistem politik. Kebijakan publik merupakan produk dari sistem politik tersebut. Ini disebabkan oleh kebijakan publik merupakan sebuah keputusan politik yang melembaga. Kebijakan publik mempunyai empat wujud yaitu perilaku pejabat publik, pernyataan pejabat dalam forum publik, kebiasaan umum lembaga publik yang telah diterima bersama, dan kebijakan formal atau peraturan formal (Nugroho, 2017:156).

Kebijakan formal dalam wujud kebijakan publik tersebut juga dibagi menjadi tiga bentuk yaitu perundang-undangan, hukum, dan regulasi. Di dalam tulisan ini berfokus kepada perundangundangan. Kebijakan publik dalam bentuk perundang-undangan merupakan usaha pembangunan nasional baik menyentuh level negara maupun masyarakat. UU yang berhubungan dengan pembangunan menjadikannya lebih bersifat menggerakkan, dinamis, antispasi, dan inovasi (Nugroho, 2017:156).
Pemahaman kebijakan publik berupa UU juga berhubungan dengan praktik implementasinya. UU diterapkan dengan metode administrative enforcement melalui organisasi birokrasi pemerintahan. Namun tidak jarang juga bahwa UU dilaksanakan melalui metode legal enactment yaitu melalui peradilan (Nugroho, 2017:158).

Kebijakan publik juga memiliki implikasi. Menurut Anderson setidaknya terdapat lima implikasi dari kebijakan publik yaitu pertama setiap kebijakan yang diambil mempunyai sasaran yang ingin diperoleh. Kedua, kebijakan memiliki prosedur aksi yang dilakukan oleh pemerintah. Ketiga, kebijakan tersebut keinginan pemerintah untuk melakukan sesuatu. Keempat kebijakan dapat bersifat baik dan buruk. Kelima kebijakan yang baik berkarakter otoriter karena berdasarkan kepada hukum (Anderson, 1979).

\section{METODE PENELITIAN}

Tulisan mengenai dinamika pengesahan UU ormas, implementasi dan implikasinya ini merupakan penelitian kualitatif. Metode kualitatif dalam tulisan ini mampu memberikan pemahaman yang baik terhadap permasalahan yang diangkat di tulisan ini. Metode pengumpulan data dalam membantu menjawab pertanyaan dasar tulisan ini menggunakan metode pengumpulan Library Research. Metode pengumpulan melalui Library Research ini menggunakan sumber-sumber dari buku, jurnal, dan media massa online. Proses dalam pengambilan data mengunakan teknik snowball sampling. Pengoperasian teknik ini adalah dengan infomasi pertama yang diperoleh dari suatu sumber dilacak lebih dalam lagi dengan mengakses sumber lainnya untuk memperoleh informasi lebih lanjut (Salim, 2006: 13). Setelah data diperoleh, maka data tersebut dianalisis menggunakan model interaktif yang ditawarkan oleh Miles \& Huberman yang melihat empat aspek utama yaitu kondensasi data, penyajian data, dan menarik kesimpulan (Miles, Huberman, \& Saldana, 2014: 12-14).

\section{HASIL DAN PEMBAHASAN}

\section{Kelahiran Kebijakan: UU No. 16 Tahun 2017}

Keberadaan UU No. 17 Tahun 2013 selama ini tidak memudahkan pemerintah dalam menghentikan ormas-ormas yang tidak sejalan dengan pancasila, UUD 1945, NKRI dan Bhineka Tunggal Ika. UU No. 17 Tahun 2013 terlihat bahwa proses hukum yang akan dijalani akan sangat lama dan berbelit-belit. Sehingga walaupun pemerintah 
mengetahui adanya ormas yang tidak sejalan dan membahayakan negara, pemerintah cenderung tidak berani dalam melakukan tindakan.

Dengan tidak efektifnya UU No. 17 Tahun 2013 maka dikeluarkanlah Perppu No. 2 Tahun 2017. Pasca Perppu tersebut hadir tidak lama ada upaya menjadikannya UU (UU No. 16 Tahun 2017).

Berikut ini tabel pihak mendukung dan menolak Perppu ormas menjadi UU ormas

Tabel 1. Pihak Mendukung

\begin{tabular}{|c|c|c|}
\hline No. & Nama (Fraksi) & Pernyataan \\
\hline 1. & $\begin{array}{l}\text { Taufik } \\
\text { Kurniawan } \\
\text { (PAN) }\end{array}$ & $\begin{array}{l}\text { Pimpinan DPR akan } \\
\text { mendukung langkah } \\
\text { pemerintah dalam } \\
\text { melawan ormas yang } \\
\text { bertentangan dengan } \\
\text { nilai Pancasila. }\end{array}$ \\
\hline 2. & $\begin{array}{l}\text { Surya Paloh, } \\
\text { Taufiqulhadi } \\
\text { (Nasdem) }\end{array}$ & $\begin{array}{l}\text { Mendukung } \\
\text { Pemerintah dalam } \\
\text { pembentukkan UU } \\
\text { ormas karena menjaga } \\
\text { nilai-nilai NKRI. }\end{array}$ \\
\hline 3. & $\begin{array}{l}\text { Bambang } \\
\text { Soesatyo dan } \\
\text { TB. Ace Hasan } \\
\text { Syadzily } \\
\text { (Golkar) }\end{array}$ & $\begin{array}{l}\text { Jokowi sebagai kepala } \\
\text { negara telah tepat } \\
\text { melakukan penerbitan } \\
\text { Perppu No. } 2 \text { Tahun } \\
2017 \text { dalam rangka } \\
\text { menjaga keamanan } \\
\text { NKRI dan kegiatan } \\
\text { yang mengancam } \\
\text { Pancasila sebagai dasar } \\
\text { negara. }\end{array}$ \\
\hline 4. & $\begin{array}{l}\text { Romahurmuzy, } \\
\text { Arsul Sani } \\
\text { (PPP) }\end{array}$ & $\begin{array}{llr}\text { - } & \text { Perbuatan } & \text { HTI } \\
\text { termasuk makar. } \\
\text { Peluang } & \text { bagi } \\
\text { pemerintah untuk } & \text { membina } & \text { bagi } \\
\text { ormas } & \text { untuk } \\
\text { kembali ke } & \text { jalur } \\
\text { kang "benar". }\end{array}$ \\
\hline 5. & $\begin{array}{l}\text { Abdul Malik } \\
\text { Haramain } \\
\text { (PKB) }\end{array}$ & $\begin{array}{lr}\text { Perppu merupakan } \\
\text { kebutuhan } & \text { dan } \\
\text { kepentingan negara }\end{array}$ \\
\hline 6. & $\begin{array}{l}\text { Hasto } \\
\text { Kristiyanto, } \\
\text { Djarot Syaiful } \\
\text { Hidayat } \\
\text { (PDIP) }\end{array}$ & $\begin{array}{l}\text { Lewat Perppu } \\
\text { pemerintah ingin } \\
\text { menciptakan rasa aman } \\
\text { dan tenang di } \\
\text { masyarakat Apabila } \\
\text { ditemukan ormas yang } \\
\text { menentang dengan nilai } \\
\text { Pancasila maka akan } \\
\text { mudah menanganinya. }\end{array}$ \\
\hline
\end{tabular}

\begin{tabular}{|c|c|c|c|}
\hline 7. & $\begin{array}{l}\text { Dadang } \\
\text { Rusdiana } \\
\text { (HANURA) }\end{array}$ & $\begin{array}{l}\text { UU No. } 17 \text { Tah } \\
\text { menyulitkan } \\
\text { pemerintah } \\
\text { membubarkan } \\
\text { radikal. }\end{array}$ & $\begin{array}{l}\text { un } 2013 \\
\text { ormas }\end{array}$ \\
\hline 8. & $\begin{array}{l}\text { Tsamara } \\
\text { Amany } \\
\text { (PSI) }\end{array}$ & $\begin{array}{l}\text { Tidak } \\
\text { dikhawatirkan } \\
\text { ormas } \\
\text { bertentangan } \\
\text { ideologi } \\
\text { Indonesia. }\end{array}$ & $\begin{array}{r}\text { perlu } \\
\text { apabila } \\
\text { tidak } \\
\text { dengan } \\
\text { bangsa }\end{array}$ \\
\hline
\end{tabular}

Sumber: Yunanto. 2018: 166-173

Tabel 2. Pihak Menolak

\begin{tabular}{|c|c|c|}
\hline No. & $\begin{array}{c}\text { Nama } \\
\text { (Fraksi) }\end{array}$ & Pernyataan \\
\hline 1. & $\begin{array}{l}\text { Fahri Hamzah, } \\
\text { (Wakil Ketua } \\
\text { DPR) }\end{array}$ & $\begin{array}{l}\text { Perbuatan sepihak } \\
\text { dalam membubarkan } \\
\text { kelompok sosial. }\end{array}$ \\
\hline 2. & $\begin{array}{l}\text { Fadli Zon, } \\
\text { Ahmad } \\
\text { Muzani } \\
\text { (Gerindra) }\end{array}$ & 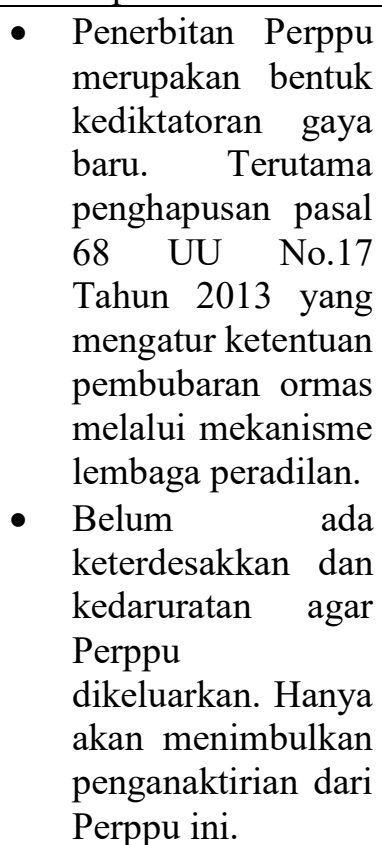 \\
\hline 3 . & $\begin{array}{l}\text { Amien Rais, } \\
\text { Yandri Susanto } \\
\text { (PAN) }\end{array}$ & 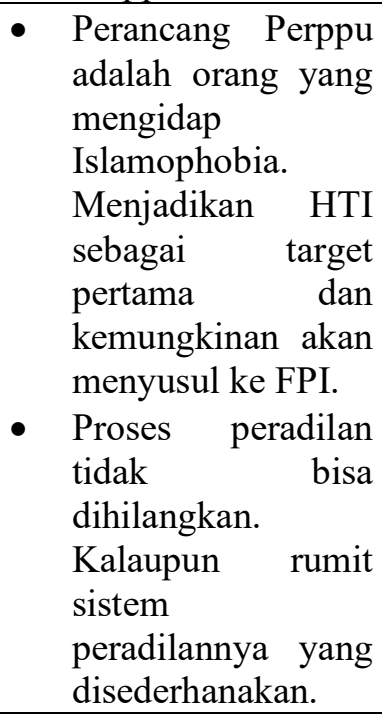 \\
\hline 4. & $\begin{array}{ll}\text { Hinca } & \text { IP } \\
\text { Pandjaitan } & \\
\end{array}$ & $\begin{array}{l}\text { Tidak ada alasan yang } \\
\text { genting dan memaksa }\end{array}$ \\
\hline
\end{tabular}

4 | Fadli Afriandi, Fachriza Ariyadi | Pro Kontra Proses...... 


\begin{tabular}{|c|c|c|}
\hline & (Demokrat) & $\begin{array}{l}\text { sebagai syarat utama } \\
\text { menerbitkan Perppu } \\
\text { sebagaimana } \\
\text { dimintakan Pasal } 22 \\
\text { ayat (1) UUD 1945 }\end{array}$ \\
\hline 5. & $\begin{array}{l}\text { Sohibul Iman } \\
\text { (PKS) }\end{array}$ & 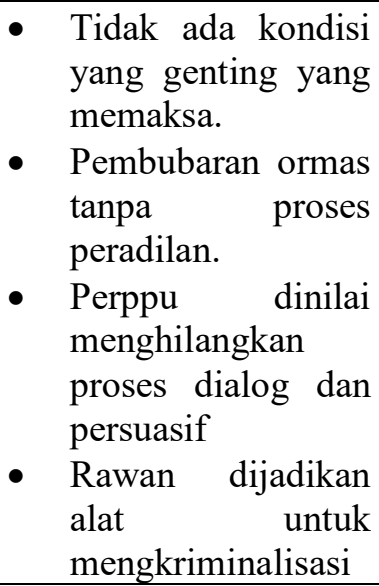 \\
\hline
\end{tabular}

Sumber: Yunanto. 2018: 197-201

Kemudian kita perlu melihat bagaimana ideologi partai di Indonesia sebagai pijakan analisis dalam mendukung maupun menolak penetapan Perppu ormas tersebut menjadi UU ormas.

Grafik 1. Partai Pancasila atau Islam

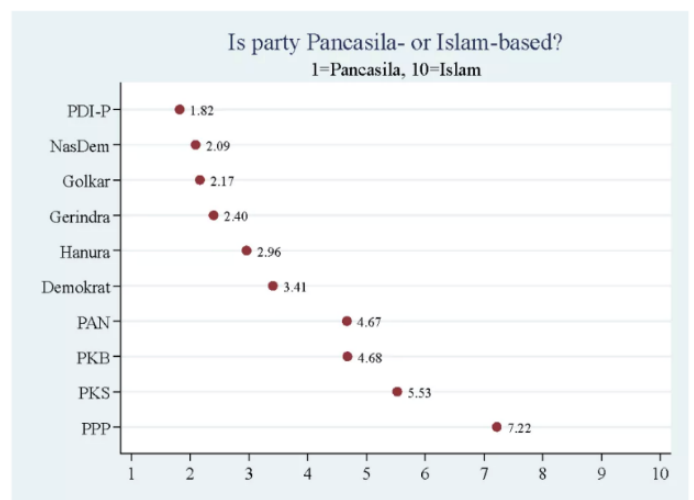

Sumber: Aspinal dkk, 2018

Grafik 2. Peran untuk Islam yang didukung partai

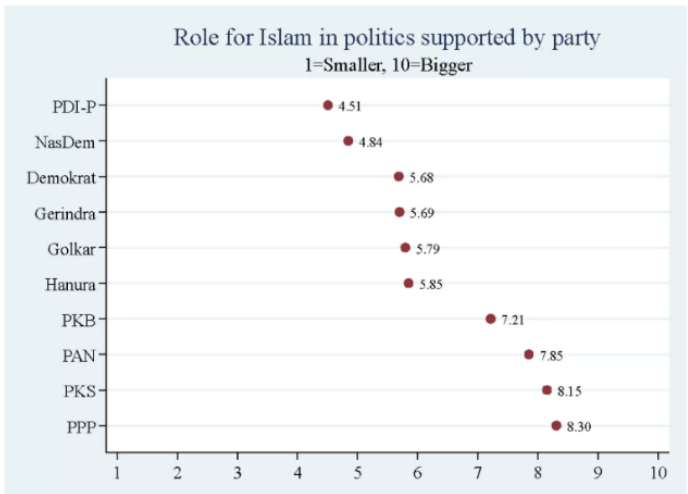

Sumber: Aspinal dkk, 2018
Grafik 3. Partai sayap kiri atau kanan

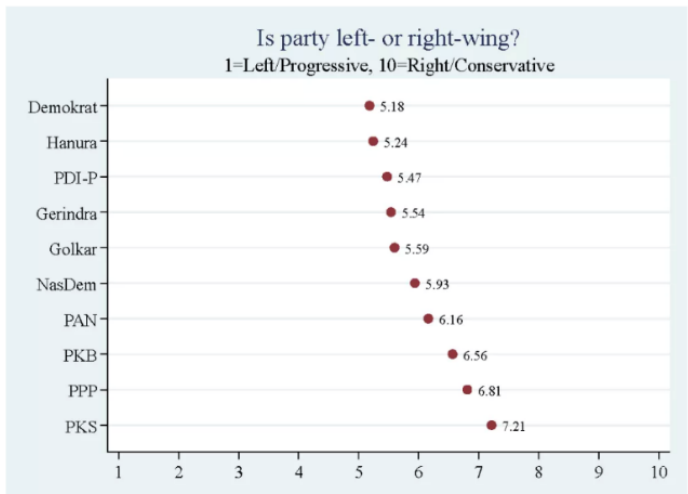

Sumber: Aspinal dkk, 2018

Bagan 1. Komposisi Hasil Penetapan Perubahan Perppu No. 2 Tahun 2017 menjadi UU No. 16 Tahun 2017

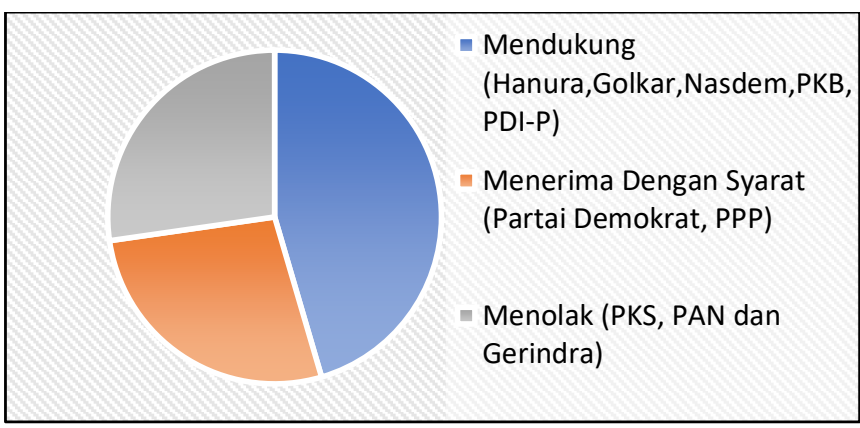

Sumber: Diolah dari beberapa sumber

Berikut adalah tabel pernyataan fraksi yang menolak, menerima dengan syarat dan menerima Perppu ormas menjadi UU ormas.

Tabel 3. Penyataan dari Fraksi yang menolak

\begin{tabular}{|c|c|c|}
\hline No. & Fraksi & Pernyataan \\
\hline 1. & Gerindra & $\begin{array}{l}\text { - Perppu ormas melanggar } \\
\text { konstitusi dan UUD } 1945 . \\
\text { - Perppu ormas terlalu } \\
\text { membatasi hak dalam } \\
\text { menyampaikan pendapat. } \\
\text { - Ada beberapa hal yang } \\
\text { sebaiknya diperbaiki dalam } \\
\text { Perppu ormas terkait } \\
\text { permasalahan lamanya } \\
\text { hukuman, subjek yang } \\
\text { dihukum, otoritas } \\
\text { pembubaran, waktu } \\
\text { pembubaran, dan intepretasi } \\
\text { Pancasila sebelum disahkan } \\
\text { menjadi UU. }\end{array}$ \\
\hline 2. & PAN & $\begin{array}{l}\text { - Perppu ormas telah } \\
\text { melenyapkan secara penuh } \\
\text { nilai-nilai demokrasi dan } \\
\text { HAM. }\end{array}$ \\
\hline
\end{tabular}

Fadli Afriandi, Fachriza Ariyadi $\mid$ Pro Kontra Proses..... $\mid 5$ 


\begin{tabular}{|c|c|c|}
\hline & & $\begin{array}{l}\text { - Perppu ormas tidak berada } \\
\text { dalam situasi dan kondisi } \\
\text { yang krusial. } \\
\text { - Perlu kepatuhan terhadap } \\
\text { Pasal } 22 \text { ayat (1) UUD 1945. } \\
\text { Ini merupakan regulasi } \\
\text { terkait penerbitan Perppu. }\end{array}$ \\
\hline 3. & PKS & $\begin{array}{l}\text { - } \text { Telah tesedia UU No. } 17 \\
\text { Tahun } 2013 \text { terkait } \\
\text { pelanggaran hukum yang } \\
\text { dilakukan oleh ormas. } \\
\text { - Ada makna ganda yang } \\
\text { memungkinkan terjadinya } \\
\text { interpretasi seperti pasal } \\
\text { karet (aturan pelarangan } \\
\text { untuk menggunakan identitas } \\
\text { dan simbol organsasi). } \\
\text { - Kehadiran otoritarianisme } \\
\text { semakin besar jika tidak } \\
\text { melibatkan pengadilan. } \\
\text { - Melahirkan kriminalisasi } \\
\text { dalam pemberian sanksi } \\
\text { pidana. }\end{array}$ \\
\hline
\end{tabular}

Sumber: Diolah dari beberapa sumber

Tabel 4. Penyataan dari Fraksi yang menerima dengan syarat

\begin{tabular}{|l|l|l|}
\hline No. & Fraksi & \multicolumn{1}{|c|}{ Penyataan } \\
\hline 1. & $\begin{array}{l}\text { Partai } \\
\text { Demokrat }\end{array}$ & $\begin{array}{l}\text { Revisi dalam dua hal, yakni } \\
\text { dimunculkannya kembali } \\
\text { proses pengadilan dalam } \\
\text { mekanisme pembubaran ormas } \\
\text { dan pengurangan hukuman } \\
\text { pidana yang bisa mencapai } \\
\text { seumur hidup. }\end{array}$ \\
\hline 2. & PPP & $\begin{array}{l}\text { Tindakan pemerintah dinilai } \\
\text { telah berjalan dengan baik } \\
\text { dalam mengantisipasi } \\
\text { munculnya Ormas yang } \\
\text { menciptakan disintegrasi NKRI } \\
\text { dan yang kontra terhadap } \\
\text { Pancasila }\end{array}$ \\
\hline
\end{tabular}

Sumber: (Hakim, 2017)

Tabel 5. Pernyataan dari Fraksi yang menerima

\begin{tabular}{|c|c|c|}
\hline No. & Fraksi & Pernyataan \\
\hline 1. & $\begin{array}{l}\text { PDI } \\
\text { Perjuangan }\end{array}$ & $\begin{array}{l}\text { Sebuah keharusan dalam } \\
\text { menjaga NKRI dari Ormas } \\
\text { yang anti-Pancasila yang } \\
\text { disebabkan ketiadaan } \\
\text { hukum konkret untuk } \\
\text { menyelesaikan persoalan } \\
\text { ormas yang dituding } \\
\text { berupava merongrong }\end{array}$ \\
\hline
\end{tabular}

6| Fadli Afriandi, Fachriza Ariyadi| Pro Kontra Proses......

\begin{tabular}{|c|c|c|}
\hline & & $\begin{array}{l}\text { Pancasila (Sasongko, } \\
\text { 2017). }\end{array}$ \\
\hline 2. & Golkar & $\begin{array}{lr}\text { Menitikberatkan } & \text { untuk } \\
\text { lawan ormas } & \text { yang tidak } \\
\text { pro-Pancasila } & \text { sebagai } \\
\text { ideologi negara. } & \end{array}$ \\
\hline 3. & PKB & $\begin{array}{l}\text { Langkah dalam mencegah } \\
\text { paham yang berlawanan } \\
\text { dengan Pancasila baik yang } \\
\text { dari individu maupun } \\
\text { kelompok }\end{array}$ \\
\hline 4. & NasDem & $\begin{array}{l}\text { Mendukung semua } \\
\text { kebijakan yang diambil } \\
\text { oleh pemerintah untuk } \\
\text { menjaga integritas NKRI, } \\
\text { menjaga nilai Pancasila, } \\
\text { keutuhan bangsa, dan } \\
\text { Bhinneka tunggal Ika } \\
\text { dalam Perppu ormas. }\end{array}$ \\
\hline 5. & Hanura & $\begin{array}{l}\text { Menilai bahwa UU } \\
\text { sebelumnya dan Perppu } \\
\text { belum mampu menangani } \\
\text { ormas yang tidak pro } \\
\text { terhadap Pancasila dan } \\
\text { ormas Radikal. Kehadiran } \\
\text { UU dan Perppu } \\
\text { sebelumnya terkesan } \\
\text { berbelit-belit dalam } \\
\text { menangani Ormas yang } \\
\text { terindikasi merusak } \\
\text { kesatuan Indonesia. }\end{array}$ \\
\hline
\end{tabular}

Sumber: (Panjimas.com, 2017)

Hasil dari perdebatan yang panjang antara kubu yang pro dengan kubu yang kontra tentang perubahan Perppu tersebut yang mana sebagian besar fraksi menerima. Penerimaan fraksi yang ada di parlemen jika kita melihat kurva di atas dapat dianalisis bahwa pertama dengan berdasarkan apakah partai berdasarkan Pancasila atau berbasis Islam. Penemuannya adalah banyak partai yang berbasis Islam mendukung perubahan Perppu tersebut menjadi undang-undang. Kedua, melihat bahwa apakah peran Islam berkontribusi terhadap Partai. Ditemukan bahwa partai yang berperan untuk Islam-pun mendukung penggantian Perppu ini menjadi UU. Ketiga, melihat kepada partai lebih cenderung ke sayap kiri atau kanan. Faktanya kecenderungan inipun tidak berpengaruh kepada proses penentuan hasil untuk mendukung atau menolak.

Tindakan PAN tergolong unik. Meskipun PAN adalah partai pendukung pemerintah (di tahun 2017) namun sikap PAN justru tidak menyetujui Perppu Ormas tersebut menjadi UU. 
Ketidakberpihakkan PAN terhadap kubu koalisi dikarenakan sikap PAN yang tidak menginginkan pemerintah menafsirkan sendiri Pancasila.

UU ormas menggolongkan ormas yang membahayakan eksistensi negara sebagai berikut:

1. Perbuatan yang menimbulkan perselisihan berdasarkan identitas suku, agama, ras atau antar golongan (SARA).

2. Perbuatan merendahkan suatu agama yang diakui di Indonesia.

3. Perbuatan yang merugikan publik baik moril maupun materil termasuk sarana dan prasarana publik.

4. Perbuatan yang tidak sesuai dengan seharusnya. Misalnya melakukan perbuatan yang seharusnya menjadi pekerjaan institusi hukum.

5. Melakukan kegiatan separatis.

6. Memproduksi, dan mendistribusi ideologi yang berlainan dengan Pancasila (Yunanto. 2018: vii).

\section{Implementasi dan Implikasi Kebijakan: UU No. 16 Tahun 2017 Terhadap Ormas Keagamaan}

Implementasi UU ormas memberikan sanksi kepada ormas terkhusus penambahan sanksi pidana. Dalam UU ormas juga terdapat absennya asas contrarius actus yang membuat pemerintah melalui Kementerian Hukum dan Hak Asasi Manusia atau Kemenkumham mempunyai kewenangan tanpa batas dalam menentukan status sebuah ormas. Dalam implementasi UU ormas ini terdapat juga bahwa ormas tidak dapat melakukan kegiatan baik internal maupun eksternal tanpa izin. Hal yang menguntungkan bagi pemerintah dalam mengontrol ormas juga terlihat dari asas contrarius actus yang menihilkan prosedur hukum (proses peradilan) (Kahono, Junaidi, \& Nuswanto, 2020).

Meskipun dengan pengambilalihan perubahan status ormas (hingga pembubaran ormas) tidak memerlukan waktu yang lama. Namun penerapan asas tersebut belum melihatkan sistem demokrasi yang baik antara pemisahan lembaga eksekutif dan yudikatif. Selain itu UU ormas yang telah disahkan juga belum mencerminkan perlindungan HAM. Dengan pembubaran di lembaga eksekutif dapat menimbulkan penilaian subjektif pemerintah terhadap ormas tersebut (Amer, 2020).

Dampak dari pelaksanaan UU ormas ini setidaknya membuat pemerintah dapat mencabut status dari ormas tersebut tanpa proses peradilan.
Pencabutan status ormas tersebut dapat dilakukan melalui Kemenkumham. Salah satu korban pasca disahkannya UU ormas dan dari proses ini adalah pembubaran FPI tanpa proses peradilan.

Disahkan Perppu ormas menjadi UU ormas juga mengharuskan ormas untuk melakukan pendaftaran dan memiliki Surat Keterangan Terdaftar (SKT). Pendaftaran ini dapat memudahkan pemerintah dalam mengontrol ormas yang tidak sesuai dengan cita-cita negara atau melanggar konstitusi nantinya. Pendaftaran ormas memberikan peran yang besar bagi pemerintah kabupaten/kota untuk mengeluarkan kebijakan lokal terkait mekanisme pendaftaran. Terkait SKT bahwasannya ormas semakin jelas mana ormas yang diakui pemerintah dan mana yang tidak diakui oleh pemerintah. Dalam penerapan adanya SKT ini menyebabkan bahwa kepemilikan SKT dapat menghilangkan kelompok minoritas (Abdali, Rofiandri, \& Fadhli, 2018).

Perubahan Perppu ormas menjadi UU ormas telah disahkan oleh DPR RI yang merupakan lembaga legislatif di Indonesia. Penerapan UU ormas ini memberikan kelebihan bagi pemerintah untuk mengontrol dan mengawasi ormas lebih ketat. Pasca UU ormas ini disahkan terlihat ruang gerak ormas semakin sempit yang mengakibatkan eksistensi ormas di lingkungan masyarakat semakin menurun (Abdali, Rofiandri, \& Fadhli, 2018).

\section{Kebijakan Pembubaran FPI: Dampak dari UU ormas}

FPI didirikan pasca lengsernya Soeharto dari kursi presiden tepatnya empat bulan setelah Soeharto mengundurkan diri sebagai presiden. 17 Agustus 1998 beberapa ulama mendeklarasikan berdirinya ormas tersebut yang terdiri dari Habib Rizieq Shihab, Habib Idrus Jamalullail, dan Kiai Misbach. Latar belakang berdirinya FPI dipengaruhi oleh tiga hal yaitu tanggung jawab ulama Islam terhadap sang pencipta terkait makin rusaknya moral, keharusan untuk menjunjung amar ma'ruf nahi munkar, dan kurangnya pengawasan pemimpin sipil dan militer terhadap hak penduduk muslim sebagai penduduk mayoritas (Anwar, 2014: 224).

FPI adalah ormas Islam yang didirikan bertujuan untuk melakukan amar ma'ruf nahi munkar yaitu menyiarkan kebaikan dan mencegah keburukan sesuai dengan hukum Islam dan hukum akal sehat. FPI juga menjalankan organisasinya dengan cara bijaksana dan kerahamah-tamahan 
dengan berdiskusi dan saling memberikan nasihat. Tujuan berikutnya FPI dibentuk juga sesuai dengan tujuan ormas di negara demokrasi yaitu menjadi kolega pemerintah dalam memerangi keburukan. Namun dalam perjalanannya, tujuan FPI hadir cukup mulia namun pelaksanaannya jauh dari nilai-nilai awal FPI (Damaitu \& Wada, 2017 :154).

Aksi FPI di tengah masyarakat sering bertabrakan dengan masyarakat. Kegiatan sweeping yang dilakukan FPI tanpa izin dari pihak kepolisian adalah contoh over lapping-nya kewenangan dari FPI yang seharusnya dilaksanakan oleh Polisi Republik Indonesia (POLRI). Selain itu dalam aksinya FPI sering melanggar aturan hukum yang berlaku seperti aksi kekerasan, mengganggu kenyamanan, ketentraman, dan ketertiban umum hingga merusak sarana dan prasarana publik (Damaitu \& Wada, $2017: 152$ ).

Di masa lalu, 19 Juli 2017 Perppu ormas telah berhasil membubarkan ormas Islam Hizbut Tahrir Indonesia (HTI) dengan tanpa proses peradilan di pengadilan. HTI dibubarkan dengan mencabut status hukumnya oleh Menteri Hukum dan HAM. Sesuai dengan penyataan fraksi PAN Amien Rais dan Yandri Susanto dalam hal menolak disahkannya UU ormas yang telah dipaparkan di atas bahwasannya FPI adalah target berikutnya pemerintah membubarkan ormas. Maka pada tanggal 30 Desember 2020 pernyataan fraksi PAN tersebut terbukti bahwasannya FPI dibubarkan oleh pemerintah (Amirullah, 2021).

FPI adalah korban kedua ormas Islam yang dibubarkan tanpa proses peradilan yang memang sesuai dengan UU ormas. FPI dibubarkan oleh lembaga eksekutif bukan yudikatif. FPI dibubarkan pasca dikeluarkan Surat Keputusan Bersama Menteri Hukum dan HAM, Menteri Komunikasi dan Informatika, Menteri Dalam Negeri, Jaksa Agung, Kepala Kepolisian Negara Republik Indonesia, dan Kepala Badan Nasional Penanggulangan Terorisme. Ada beberapa alasan ormas ini dibubarkan. Pertama, FPI tidak lagi mengantongi SKT yang merupakan syarat wajib dari UU ormas. Kedua, AD/ART FPI bertentang dengan UU ormas. (Wibowo, 2020). AD/ART FPI tidak mencantumkan Pancasila sebagai asas ormas tersebut melainkan ajaran Islam. Selain itu alasan pemerintah membubarkan FPI adalah para anggota FPI tercatat sering melakukan tindak pidana kejahatan (Nathaniel, 2021).

8 |Fadli Afriandi, Fachriza Ariyadi | Pro Kontra Proses......

\section{KESIMPULAN}

Tulisan ini melihat kepada dinamika pengesahan UU ormas sehingga melahirkan kebijakan dari pertarungan fraksi yang ada di parlemen, implementasi dan implikasinya dari kebijakan tersebut. Berawal dari pengesahan Perppu ormas menjadi UU ormas dimana adanya perbedaan pendapat beberapa fraksi di parlemen. UU ini dirasa perlu bagi yang mendukung pengesahan UU tersebut dikarenakan UU sebelumnya belum mampu melakukan tindakan langsung dan cepat terhadap ormas yang berbeda ideologi dengan ideologi Pancasila. Perbedaan ideologi ini nantinya akan mengancam kepada keutuhan NKRI. Namun beberapa pihak merasa bahwa pengesahan Perppu ormas menjadi UU ormas belumlah diperlukan karena beberapa faktor. Misalnya belum adanya keadaan genting dan mendesak untuk Perppu tersebut disahkan menjadi UU. Selain itu juga menilai bahwa UU ormas melihatkan kemunduran demokrasi dimana salah satu pasal dihilangkan yang menyangkut ormas tidak perlu mengalami proses peradilan.

Berdasarkan ideologi partai, pertama, keputusan yang diambil oleh partai baik menerima maupun menolak terlihat bahwa dominan partai mendukung adalah partai yang pro kepada Pancasila. Namun Gerindra yang berbasis kepada Pancasila malah menolak pengesahan Perppu tersebut. Kedua, apabila dianalisis dengan partai yang berbasis kepada Islam, partai Islam seperti PKB dan PPP setuju dengan pengesahan Perppu menjadi UU terkait ormas. Ini melihatkan bahwa partai di Indonesia masih belum konsisten kepada ideologi yang melatarbelakangi mereka. Ini dapat terkait kepada kepentingan tiap partai melebihi kepedulian mereka terhadap sebuah ideologi partai.

Dalam implementasi UU ormas tersebut terdapat beberapa hal yang menjadi pusat perhatian yaitu terkait asas contrarius actus yang tidak lagi melewati lembaga yudikatif. Asas contrarius actus memberikan hak kepada lembaga eksekutif dalam hal ini Kemenkumham dalam memutuskan suatu ormas untuk dizinkan atau dihentikan status hukumnya. Meskipun asas contrarius actus dibenarkan namun dalam sistem demokrasi sudah ada pembagian yang jelas antara tugas dan wewenang lembaga eksekutif maupun yudikatif. Sehingga keputusan pencabutan status hukum oleh lembaga eksekutif cacat di mata demokrasi. Selain asas contrarius actus adalah terkait SKT yang memberatkan ormas beroperasi. SKT menjadi alat 
negara untuk merestui atau tidak suatu ormas dapat beroperasi.

Setelah disahkan UU ormas tersebut, sejalan dengan penerapannya ternyata berdampak kepada salah satu ormas keagamaan di Indonesia. FPI sebagai ormas Islam yang mempunyai massa besar harus dibubarkan sesuai dengan ketentuan UU ormas yang telah disahkan tersebut. FPI dihentikan status hukum dan dibubarkan tanpa melewati peradilan namun oleh lembaga eksekutif dengan dikeluarkan SKB tiga Menteri dan tiga lembaga tinggi negara lainnya.

\section{REFERENSI}

Abdali, R.I., Rofiandri, R., \& Fadhli, M. 2018. Laporan Monitoring dan Evaluasi Implementasi Tahun Kelima. Jakarta: Koalisi Kebebasan Berserikat

Amer, N. 2020. Analisis Pembubaran Organisasi Kemasyarakatan dalam Perspektif Negara Hukum. Jurnal Legalitas, 13(1), 1-15

Amirullah. 2021. FPI Dibubarkan, Rizieq Shihab Minta Pengikutnya Rileks. Diakses melalui

https://nasional.tempo.co/read/1419642/fpidibubarkan-rizieq-shihab-minta-

pengikutnya-rileks/full\&view $=$ ok pada tanggal 30 Maret 2021

Anderson, J. E. 1979. Public Policy Making. New York: Holt, Rinehart and Winston

Anderson, J.E. 2003. Public Policymaking: An Introduction. Boston: Houghton Mifflin Company

Anwar, S. 2014. Pemikiran dan Gerakan Amar Ma'ruf Nahi Munkar Front Pembela Islam (FPI) di Indonesia. Teosofi: Jurnal Tasawuf dan Pemikiran Islam, 4(1), 220-250

Aspinall, E dkk. 2018. Mapping the Indonesian political spectrum. Diakses dari http://www.newmandala.org/mappingindonesian-political-spectrum/

Damaitu, E. R., \& Wada, I.A. 2017. Wewenang Pemerintah dalam Pembubaran Organisasi Masyarakat. e-Journal Lentera Hukum, 4(3), 150-163

Dye, T.R. 1972. Understanding Public Policy. New Jersey: Prince-Hall
Hairi, P. J. 2017. Landasan Hukum Rencana Pembubaran Organisasi Kemasyarakatan. Info Hukum. IX (10)

Hakim, R. N. 2017. Tujuh Fraksi Terima Perppu Ormas, Tiga Fraksi Menolak. Diakses dari https://nasional.kompas.com/read/2017/10/ 23/15413301/tujuh-fraksi-terima-perppuormas-tiga-fraksi-menolak Pada tanggal 10 Januari 2020

Herdiansah, A. G. \& Randi. 2016. Peran Organisasi Masyarakat (Ormas) dan Lembaga Swadaya Masyarakat (LSM) dalam Menopang Pembangunan di Indonesia. Jurnal Sosioglobal, 1(1), 49-67

Hidayat, M. 2008. Ormas Keagamaan dalam Pemberdayaan Politik Masyarakat Madani. Jurnal Komunitas: Pengembangan Masyarakat Islam , 4(1), 5-22

Kahono, S., Junaidi, M., \& Nuswanto, A. H. 2020. Tinjauan Yuridis terhadap Ketentuan Asas Contrius Actus Menurut UU No. 16 Tahun 2017 Tentang Penetapan Peraturan Pemerintah Pengganti Undang-Undang No. 2 Tahun 2017 tentang Perubahan Atas Undang-Undang Nomor 17 Tahun 2013 Tentang Organisasi Masyarakat. Semarang Law Review, 1(1), 89-103

Keane, J. 1998. Civil Society: Old Images, New Vissions. New Jersey: Princeton University Press

Kusumanegara, S. 2010. Model dan Aktor dalam Proses Kebijakan Publik. Yogyakarta: Gava Media

Laswell, H.D. 1956. The Decision Process: Seven Category of Functional Analysis. University of Maryland: Bureau of Government Research, College of Business and Public Administration

Latifah \& Larasati, D. 2018. Demokrasi dan Organisasi Masyarakat Sipil: Malang Corruption Watch. Jurnal Sospol, 4(1), 168184

Miles, M.B., Huberman, A.M., \& Saldana, J. (2014). Qualitative Data Analysis, A Methods Sourcebook, Edition 3. USA: Sage Publications. Terjemahan Tjetjep Rohindi Rohidi. UI-Press

Mirahmadi, H., Ziad, W., Farooq, M., \& Lamb, R. 2016. Empowering Pakistan's Civil Society to Counter Violent Extremism. 
Contemporary Readings in Law \& Social Justice, 8(1), 188-214.

Nathaniel, F. 2021. Bagaimana Perppu Ormas Jadi Jalan Pintas Pemerintah Bubarkan FPI?. Diakses melalui https://irto.id/f9gr Pada Tanggal 30 Maret 2021

Panjimas.com. 2017. Catat! Ini Fraksi yang Mendukung dan Menolak Perppu Ormas. Diakses dari http://www.panjimas.com/news/2017/07/19 /catat-ini-fraksi-yang-mendukung-danmenolak-perppu-ormas/

Probosiwi, R. 2018. Peran Organisasi Masyarakat Sipil dalam Penciptaan Keserasian Sosial. Jurnal Penelitian Kesejahteraan Sosial, 17(4), 389-400

Putnam, R. D dkk. 1993. Making Democracy Work: Civic Traditions in Modern Italy. New Jersey: Princeton University Press

Salim, A. 2006. Teori \& Paradigma Penelitian Sosial. Yogyakarta: Tiara Wacana

Sasongko, J.P. 2017. Fraksi PDIP Ungkap Alasan Dukung Perppu Ormas. Diakses dari https://www.cnnindonesia.com/nasional/20 171024171536-32-250700/fraksi-pdipungkap-alasan-dukung-perppu-ormas

Tocqueville, A.D. 2005. Revolusi, Demokrasi dan Masyarakat. Jakarta: Yayasan Obor Indonesia

Wibowo, K. S. 2020. FPI Dilarang, Pakar Hukum Kritik UU Ormas yang Khas Orde Baru. Diakses melalui https://nasional.tempo.co/read/1418861/f pi-dilarang-pakar-hukum-kritik-uuormas-yang-khas-ordebaru/full\&view=ok Pada tanggal 30 Maret 2021

Yunanto, S. 2018. Menata Ormas Memperkuat Bangsa. Jakarta: Multi Inovasi Mandiri 